\title{
Isolasi Bakteri Mananolitik dan Karakterisasi Mananasenya
}

\author{
Isolation of Mananolitic Bacteria and Characterization of Its Mannanase
}

\author{
Anja Meryandini*, Rizky Anggreandari, Nisa Rachmania \\ Departemen Biologi, FMIPA IPB Gedung Fapet Lt 5 Wing 1 Kampus Darmaga Institut Pertanian Bogor \\ E-mail: ameryandini@ yahoo.com*Penulis untuk korespondensi
}

\begin{abstract}
Isolate RA05 has the highest mannanolytic index and mannanase activity which isolated from copra soil waste from Pasaman, West Sumatra. The best growth condition that produces best mannanase activity of isolate RA05 was achieved from $500 \mathrm{ml}$ flask containing $100 \mathrm{ml}$ medium with $100 \mathrm{rpm}$ agitation. Isolate RA05 showed its mannanase activity in medium containing Locust Bean Gum and coconut meal but not in medium containing kolang kaling. This mannanase had the highest activity on medium containing $2 \%$ of coconut meal with optimum condition temperatur $80^{\circ} \mathrm{C}$ and pH 2.5. Adding of $5 \mathrm{mM} \mathrm{MnCl}$ on the crude enzym increased the activity near $300 \%$. Other kation $\left(\mathrm{Ca}^{2+}, \mathrm{Zn}^{2+}, \mathrm{Cu}^{2+}, \mathrm{Mg}^{2+}, \mathrm{Fe}^{2+}\right.$ dan $\left.\mathrm{Co}^{2+}\right)$ did not display great effect on the activity.
\end{abstract}

Key words: optimasi, karakterisasi, mananase

Diterima: 20 Maret 2007, disetujui: 27 Februari 2008

\section{Pendahuluan}

Peningkatan hasil pertanian diikuti pula oleh meningkatnya limbah hasil pertanian yang bila tidak ditangani akan menimbulkan masalah lingkungan. Komponen limbah pertanian umumnya adalah selulosa dan hemiselulosa (xilan dan manan). Salah satu produk pertanian adalah kelapa dengan limbahnya berupa bungkil kelapa. Komponen utama bungkil kelapa adalah manan yang dapat dihidrolisis oleh mananase.

Mananase adalah enzim pengurai manan dan galaktomanan menjadi manosa dan galaktosa. Enzim ini memotong secara acak rantai utama manan dan hetero $\beta$-D-manan menjadi gula terlarut yaitu manodekstrin dan manosa (Johnson, 1990). Mananase dapat dihasilkan oleh berbagai mikroorganisme. Untuk dapat menghidrolisis (hetero) manan, fungi dan bakteri harus menghasilkan sedikitnya 3 jenis enzim yaitu satu mananase (EC 3.2.1.78), satu $\beta$-manosidase (EC 3.2.1.25) dan satu $\alpha$-galaktosidase (EC 3.2.1.22) (Hilge et al., 1998).

Enzim mannanase dapat dimanfaatkan oleh industri pulp dan kertas untuk proses pemutihan sehingga mengurangi pemakaian bahan kimiawi (Johnson, 1990) maupun dalam industri pakan ternak untuk meningkatkan nilai gizi bahan pakan kaya manan seperti bungkil kelapa. Kadar manan yang tinggi pada bungkil kelapa akan melindungi molekul protein sehingga menurunkan nilai ketercernaan protein. Daya cerna protein optimum dapat dicapai bila kandungan manannya diuraikan terlebih dahulu (Purwadaria et al., 1994).

Tujuan penelitian ini adalah untuk mengisolasi bakteri penghasil mananase dari sampel tanah limbah kopra kabupaten Pasaman Sumatra Barat. Mananase dari isolat terpilih akan dikarakterisasi yang meliputi kondisi pertumbuhan, $\mathrm{pH}$ optimum, suhu optimum, penguraian pada substrat berupa galaktomanan, bungkil kelapa, pengaruh kation terhadap aktivitas mananase dan stabilitas enzim. 


\section{Metode Penelitian}

\section{Isolasi bakteri penghasil mananase}

Isolasi bakteri dilakukan dengan melarutkan 1 gram sampel tanah ke dalam 20 $\mathrm{ml}$ medium isolasi $(0.3 \%$ gum locust bean, $0.075 \%$ pepton, $0.05 \%$ ekstrak khamir, dan campuran mineral menurut Mandels \& Sternberg (1976) yaitu $0.14 \%\left(\mathrm{NH}_{4}\right)_{2} \mathrm{SO}_{4}, 0.2 \%$ $\mathrm{KH}_{2} \mathrm{PO}_{4}, \quad 0.03 \% \quad \mathrm{MgSO}_{4} .7 \mathrm{H}_{2} \mathrm{O}, \quad 0.03 \%$ $\mathrm{CO}\left(\mathrm{NH}_{2}\right)_{2}, \quad 0.03 \% \quad \mathrm{CaCl}_{2}, \quad 0.0005 \%$ $\mathrm{FeSO}_{4} \cdot 7 \mathrm{H}_{2} \mathrm{O}, \quad 0.00016 \% \quad \mathrm{MnSO}_{4} \cdot \mathrm{H}_{2} \mathrm{O}$, $0.00014 \% \quad \mathrm{ZnSO}_{4} .7 \mathrm{H}_{2} \mathrm{O}, \quad 0.0002 \% \quad \mathrm{CoCl}_{2}$ ), diinkubasi pada suhu $37^{\circ} \mathrm{C}$ dalam inkubator berpenggoyang selama 48 jam kemudian disebar pada medium padat dengan komposisi yang sama.

\section{Pengukuran aktivitas mananase}

Uji kualitatif mananase dilakukan dengan mengukur Indeks Mananolitik (IM). IM merupakan nisbah antara diameter zona bening yang terbentuk dengan diameter koloni. Untuk memperjelas zona bening, larutan Congo Red $0.1 \%$ dituang ke atas koloni, didiamkan 15 menit kemudian dicuci dengan larutan $\mathrm{NaCl} 2 \mathrm{M}$.

Uji kuantitatif dilakukan dengan menguji aktivitas ekstrak kasar enzim. Ekstrak kasar enzim dipisahkan dari massa sel dengan sentrifugasi pada kecepatan 8400 g selama 15 menit pada suhu $4^{0} \mathrm{C}$. Aktivitas mananase diukur pada suhu $40^{\circ} \mathrm{C}$ selama 30 menit dengan metode Dinitrosalisilic Acid (DNS) berdasarkan Purwadaria et al., (1994). Gula pereduksi yang dihasilkan diukur absorbansinya pada panjang gelombang 540 nm. Satu nkat aktivitas mananase adalah banyaknya enzim yang dapat menghasilkan 1 nmol manosa dalam 1 menit. Kadar protein diukur mengikuti metode Bradford (1976). Aktivitas spesifik mananase ditentukan berdasar kadar protein.

\section{Pengaruh kondisi pertumbuhan}

Isolat yang terpilih ditumbuhkan dalam 2 kondisi yang berbeda selama 48 jam. Kondisi A adalah kondisi pertumbuhan pada $100 \mathrm{ml}$ medium manan dalam erlenmeyer $500 \mathrm{ml}$ dengan kecepatan agitasi $100 \mathrm{rpm}$. Kondisi B adalah kondisi pertumbuhan pada $200 \mathrm{ml}$ medium dalam erlenmeyer $500 \mathrm{ml}$ dengan kecepatan agitasi $80 \mathrm{rpm}$. Pertumbuhan isolat dilakukan dengan mengukur turbiditas sel pada panjang gelombang $620 \mathrm{~nm}$ dan aktivitas mananase.

Kondisi pertumbuhan terbaik digunakan untuk optimasi medium. Aktivitas mananase diukur pada medium manan yang mengandung $0,5 \%$ Locust Bean Gum atau 0,5\% bungkil kelapa atau $0,5 \%$ kolang kaling. Aktivitas mananase juga diukur pada berbagai konsentrasi bungkil kelapa $(0,5 ; 1$ dan $2 \%)$.

\section{Karakterisasi enzim mananase}

Ekstrak kasar enzim diujikan pada berbagai $\mathrm{pH}(2,50-8,50)$ dengan selang 0,5 unit. Larutan penyangga yang digunakan adalah bufer sitrat fosfat $(\mathrm{pH} 2,50-5,50)$ dan bufer fosfat ( $\mathrm{pH} 6,00-8,50)$ dan pada suhu $30-90^{\circ} \mathrm{C}$ dengan selang $10^{\circ} \mathrm{C}$.

Enam jenis kation $\mathrm{Ca}^{2+}, \mathrm{Zn}^{2+}, \mathrm{Cu}^{2+}$, $\mathrm{Mg}^{2+}, \mathrm{Fe}^{2+}$ dan $\left.\mathrm{Co}^{2+}\right)$ yang berasal dari garam $\mathrm{CaCl}_{2}, \mathrm{ZnCl}_{2}, \mathrm{CuCl}_{2}, \mathrm{MgCl}_{2}, \mathrm{FeSO}_{4}$ dan $\mathrm{CoCl}_{2}$ ditambahkan secara terpisah dengan konsentrasi akhir masing-masing sebesar $1 \mathrm{mM}$ dan $5 \mathrm{mM}$. Penambahan beberapa jenis kation divalen dilakukan untuk mengetahui pengaruh kation divalen terhadap aktivitas enzim protease yang diinkubasi pada suhu optimum selama 30 menit.

Stabilitas mananase pada suhu dan $\mathrm{pH}$ optimum dilakukan dengan menginkubasi ekstrak kasar enzim tanpa substrat selama 5 jam. Aktivitas mananase diuji setiap 1 jam.

\section{Hasil dan Pembahasan}

\section{Isolasi bakteri penghasil mananase}

Tabel 1 memperlihatkan lima isolat bakteri penghasil mananase yang berhasil diisolasi dari tanah tempat pembuangan limbah kopra di Kabupaten Pasaman Sumatera Barat.

\section{Pengaruh kondisi pertumbuhan}

Pertumbuhan isolat RA05 pada kondisi A lebih tinggi daripada kondisi B (Gambar 1). Isolat RA05 pada kondisi A mencapai fase stasioner pada jam ke 16 dan memasuki fase kematian pada jam ke 24, sedangkan pada kondisi B isolat RA05 mencapai fase stasioner 
pada jam ke 32 dan memasuki fase kematian pada jam ke 40. Pertumbuhan suatu bakteri dipengaruhi oleh aerasi dan jumlah nutrisi. Kelarutan oksigen dalam air yang rendah dan penggantian oksigen melalui difusi yang berjalan lambat merupakan faktor penghambat bagi bakteri yang hidup secara aerob (Madigan et al., 2006). Volume larutan yang meningkat juga akan menurunkan transfer dan absorbsi oksigen per unit volume medium (Wang et al., 1979). Agitasi merupakan salah satu cara mempercepat penggantian oksigen dalam medium. Adanya aerasi yang baik akan menyebabkan pertumbuhan yang cepat dari bakteri aerob sehingga mempercepat datangnya fase stasioner pada pertumbuhan dengan sistim tertutup (batch culture). Aktivitas mananase diperlihatkan pada Gambar 2. Enzim ekstraseluler sering dikeluarkan pada fase pertumbuhan stasioner. Kondisi A kemudian digunakan sebagai kondisi pertumbuhan pada uji selanjutnya.

Aktivitas spesifik mananase isolat RA05 pada medium $0,5 \%$ bungkil kelapa lebih tinggi 3 nkat/mg daripada aktivitasnya pada medium 0,5\% Locust Bean Gum (Tabel 2). Mananase isolat RA05 tidak menunjukkan aktivitas pada medium $0,5 \%$ kolang kaling.

Tabel 1. Hasil isolasi bakteri penghasil mananase asal tanah tempat pembuangan limbah kopra Kabupaten Pasaman Sumatera Barat

\begin{tabular}{ccccc}
\hline \hline Isolat & Indeks mananolitik & Akt. mananase (nkat/ml) & Kadar protein (mg/ml) & Akt. Spesifik(nkat/mg) \\
\hline \hline RA01 & 0,25 & 0,74 & 0,35 & 2,11 \\
RA02 & 0,50 & 1,86 & 0,37 & 5,03 \\
RA03 & 0,25 & 0,38 & 0,36 & 1,06 \\
RA04 & 0,60 & 2,58 & 0,41 & 6,29 \\
RA05 & 0,75 & 2,58 & 0,32 & 8,06 \\
\hline \hline
\end{tabular}

Tabel 2. Aktivitas mananase isolat RA05 pada beberapa medium

\begin{tabular}{lccc}
\hline \hline & 0,5\% Locust Bean Gum & 0.5\% bungkil kelapa & 0.5\% kolang kaling \\
\hline \hline Akt. Mananase (nkat/ml) & $2,96 \pm 0,7$ & $9,60 \pm 1$ & 0 \\
Kadar protein $(\mu \mathrm{g} / \mathrm{ml})$ & $29 \pm 1,1$ & $91 \pm 2$ & 0 \\
Akt. Spesifik (nkat/mg) & $102 \pm 1,4$ & $105 \pm 1,7$ & 0 \\
\hline \hline
\end{tabular}

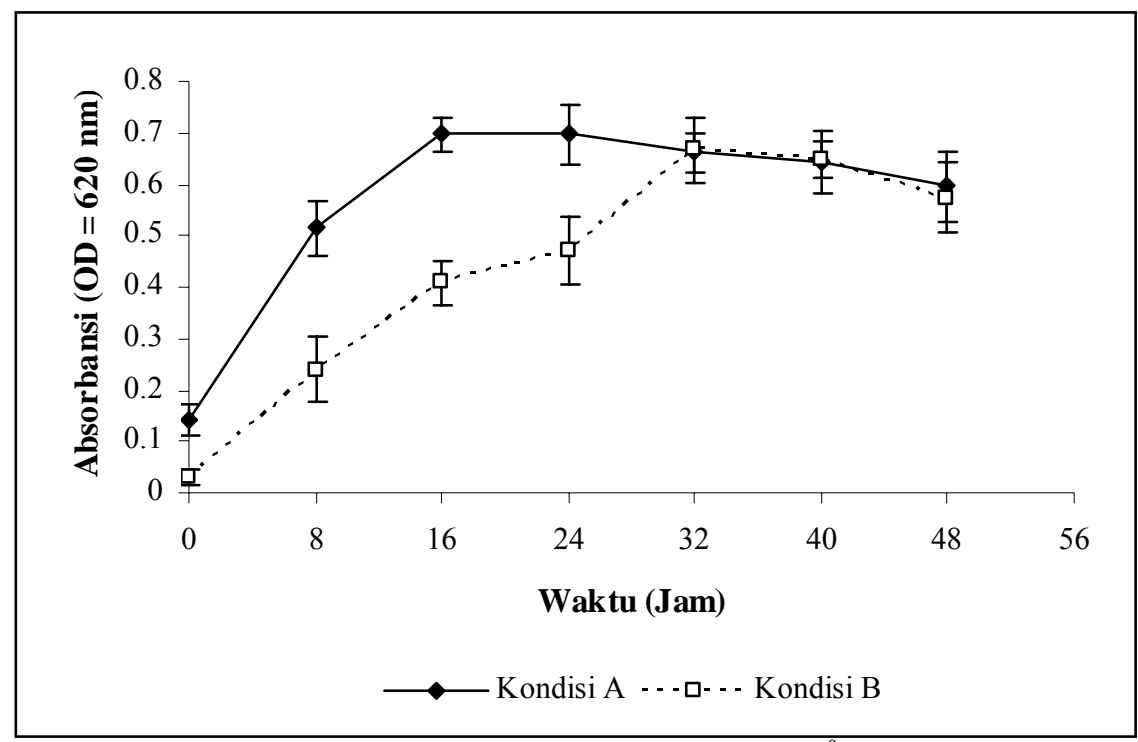

Gambar 1. Kurva pertumbuhan isolat RA05 pada suhu $37^{0} \mathrm{C}$. Kondisi A kondisi pertumbuhan pada $100 \mathrm{ml}$ medium manan dalam erlenmeyer $500 \mathrm{ml}$ dengan kecepatan agitasi $100 \mathrm{rpm}$. Kondisi B adalah kondisi pertumbuhan pada $200 \mathrm{ml}$ medium dalam erlenmeyer $500 \mathrm{ml}$ dengan kecepatan agitasi $80 \mathrm{rpm}$. 
Hal serupa dilaporkan oleh Iriani et al., (1994) pada mananase dari Eupenicillium javanicum dan Aspergillus niger, namun Sumardi (2004) melaporkan bahwa Geobacillus stearothermophilus L-07 menunjukkan aktivitas mananase pada medium yang mengandung Locust Bean Gum, kolang kaling dan umbi suweg, namun tidak pada medium yang mengandung bungkil kelapa.
Aktivitas mananase isolat RA05 yang lebih tinggi pada medium yang mengandung bungkil kelapa juga dapat disebabkan viskositas medium $0,5 \%$ bungkil kelapa lebih rendah daripada Locust Bean Gum. Hal ini membuat oksigen yang diperlukan untuk pertumbuhan bakteri lebih baik sehingga akan meningkatkan produksi enzim.

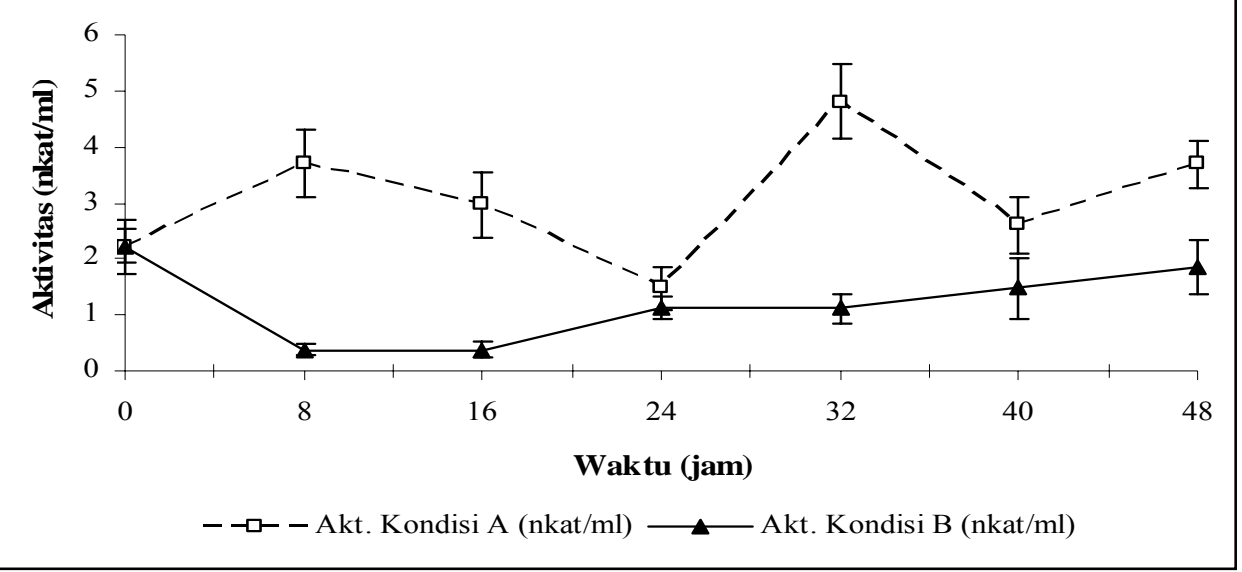

Gambar 2. Kurva aktivitas mananase isolat RA05 pada suhu $40^{\circ} \mathrm{C}$ dan $\mathrm{pH} 7,2$ pada kondisi pertumbuhan A dan B

Tabel 3. Aktivitas mananase isolat RA05 pada berbagai konsentrasi bungkil kelapa

\begin{tabular}{ccc}
\hline \hline Konsentrasi bungkil kelapa (\%) & Waktu (jam) & Aktivitas spesifik (nkat/mg) \\
\hline \hline & 0 & $90,2 \pm 0,8$ \\
& 8 & $31,8 \pm 1,1$ \\
0,5 & 16 & $\mathbf{1 0 5 , 5} \pm 0,7$ \\
& 24 & $71,3 \pm 0,8$ \\
& 32 & $37,5 \pm 0,6$ \\
& 40 & $60,8 \pm 1,2$ \\
48 & $74,9 \pm 1,4$ \\
\hline & 0 & $22,2 \pm 0,8$ \\
& 8 & $44,4 \pm 1,7$ \\
& 16 & $61,2 \pm 0,4$ \\
& 24 & $\mathbf{8 9 , 3} \pm 1,7$ \\
& 32 & $25,5 \pm 1,1$ \\
& 40 & $71,2 \pm 1,8$ \\
& 48 & 0 \\
\hline & 0 & $74,0 \pm 1,8$ \\
& 8 & 0 \\
& 16 & $48,1 \pm 1,1$ \\
& 24 & $17,0 \pm 1,4$ \\
& 32 & $\mathbf{1 0 7 , 1} \pm 0,8$ \\
& 40 & $63,4 \pm 1,3$ \\
& 48 & $29,9 \pm 1,3$ \\
\hline \hline
\end{tabular}


Menurut de Vries dan Visser (2001) kemampuan $\beta$-mananase dalam menghidrolisis senyawa galaktomanan tergantung dari jumlah substitusi galaktosa yang terdapat pada rantai samping senyawa galaktomanan. Adanya substitusi galaktosa akan menurunkan aktivitas $\beta$-mananase. Bungkil kelapa diketahui mengandung $61 \%$ galaktomanan dari $60 \%$ karbohidrat serat (Iriani et al., 1994) dan Locust Bean Gum mengandung 88\% galaktomanan (Belitz dan Grosch, 1987).

Isolat RA05 juga ditumbuhkan pada berbagai konsentrasi bungkil $(0,5 \%, 1 \%, 2 \%)$ (Tabel 3). Aktivitas mananase tertinggi dicapai pada medium $2 \%$ bungkil kelapa pada jam ke 32 sebesar 107,1 nkat/mg. Hal ini berkaitan dengan nutrisi yang tersedia dalam medium terhadap pertumbuhan bakteri. Pertumbuhan yang tinggi akan meningkatkan produksi enzim.

Pengujian pengaruh suhu dilakukan pada medium yang mengandung bungkil kelapa $2 \%$ dan dilakukan pada $\mathrm{pH}$ 7,2. Berdasarkan Gambar 3 dapat dilihat bahwa mananase bakteri ini memiliki aktivitas optimum pada suhu $80^{\circ} \mathrm{C}$ yaitu sebesar $80.4 \mathrm{nkat} / \mathrm{mg}$, namun enzim ini juga memiliki aktivitas yang cukup tinggi pada suhu $60^{\circ} \mathrm{C}(75,4 \mathrm{nkat} / \mathrm{mg})$ dan $90^{\circ} \mathrm{C}$ (59,4 nkat/mg).

Adanya beberapa puncak aktivitas pada pengaruh suhu dapat disebabkan oleh bentuk isozim dari enzim ini. Isozim merupakan enzim yang mengkatalisis reaksi yang sama tetapi menunjukkan sifat fisika dan kimia protein yang berbeda seperti misalnya titik isoelektrik, $\mathrm{pH}$ optimum, afinitas substrat atau efek inhibitor (Hames et al., 1997). Berdasarkan suhu aktivitas optimumnya, maka enzim ini tergolong enzim yang termofil walau bakterinya hidup secara mesofil. Umumnya enzim hidrolitik yang dimanfaatkan untuk industri kebanyakan hidup termofil (Atlas, 1997). Meskipun tidak menutup kemungkinan enzim yang mempunyai aktivitas dan stabil pada suhu tinggi juga dapat dieksplorasi dari bakteri mesofil. Enzim mananase termofil juga telah diisolasi dari Thermotoga neapolitana 5068 yang mempunyai suhu optimum pada $87^{0} \mathrm{C}$ (Duffaud et al., 1997).

Pengaruh $\mathrm{pH}$ terhadap aktivitas mananase dilakukan pada medium produksi yang mengandung bungkil kelapa $2 \%$ dan diinkubasi pada suhu optimum yaitu $80^{\circ} \mathrm{C}$. Pada Gambar 4 dapat dilihat bahwa aktivitas spesifik tertinggi diperoleh pada $\mathrm{pH} 2,5$ yaitu sebesar 314,6 nkat/mg. Enzim mananase isolat ini sangat asam. Enzim mananase yang aktif pada kondisi asam juga telah diisolasi dari Aspergillus niger NRRL yaitu 3,2 (Araujo dan Ward, 1990) dan Sclerotium rolfsii yang mempunyai $\mathrm{pH}$ optimum 2,9 - 3,3 (Gubitz et al., 1996).

Penambahan beberapa jenis kation divalen dilakukan untuk mengetahui pengaruh kation divalen terhadap aktivitas mananase yang diinkubasi pada suhu dan $\mathrm{pH}$ optimum selama 30 menit. Selain itu juga dilakukan uji penambahan inhibitor $\mathrm{Na}_{2}$ EDTA (dinatrium etilen diamina tetraasetat) dengan konsentrasi akhir $1 \mathrm{mM}$ dan $5 \mathrm{mM}$. Gambar 5 memperlihatkan pengaruh pemberian kation dan EDTA terhadap aktivitas mananase.

Penambahan beberapa kation divalen memberikan pengaruh yang berbeda-beda terhadap aktivitas manase. Untuk meningkatkan aktivitasnya, enzim mananase isolat bakteri ini membutuhkan ion $\mathrm{Mn}^{2+}$ dan ion $\mathrm{Fe}^{2+}$. Penambahan ion $\mathrm{Fe}^{2+}$ sedikit meningkatkan aktifitas enzim, namun penambahan ion $\mathrm{Mn}^{2+}$ sebesar $5 \mathrm{mM}$ meningkatkan aktivitas hingga hampir 300\% (Gambar 5). Enzim mananase Streptococcus ipomoea CECT 3341 juga membutuhkan ion $\mathrm{Mn}^{2+}$ untuk meningkatkan aktivitasnya namun sangat dihambat oleh ion $\mathrm{Ag}^{+}, \mathrm{Hg}^{2+}$ dan $\mathrm{Al}^{3+}$ (Montiel et al., 2002). Mananase isolat RA05 bukan merupakan suatu metaloenzim melainkan suatu enzim yang diaktifkan oleh logam karena penambahan EDTA dengan konsentrasi akhir 1 dan $5 \mathrm{mM}$ hanya akan menurunkan aktivitas sebesar $16,5 \%$ dan $27,4 \%$.

Mananase isolat RA05 stabil sampai 4 jam pada suhu $80^{\circ} \mathrm{C}$ dan $\mathrm{pH}$ 2,5 dengan dan tanpa penambahan kation $\mathrm{Mn}^{2+}$ dan kemudian mengalami penurunan pada jam ke 5 (Gambar 6). Menurut Suhartono (1989), stabilitas enzim dipengaruhi oleh kandungan jembatan disulfida dan tingkat interaksi hidrofobik pada molekulnya. Penurunan aktivitas enzim disebabkan oleh denaturasi enzim. 


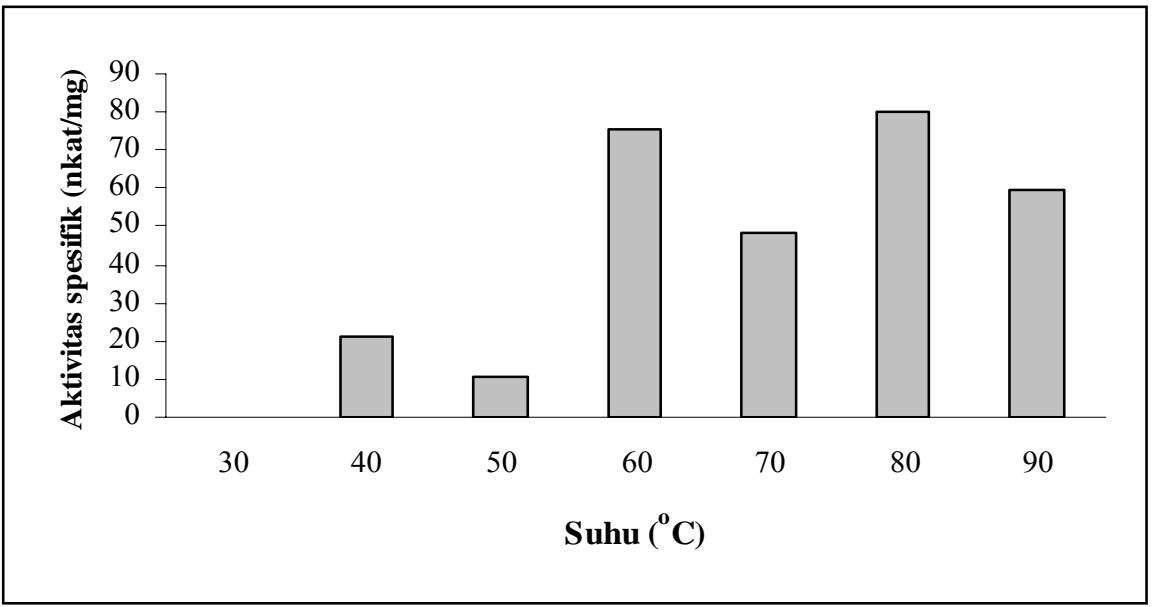

Gambar 3. Pengaruh suhu terhadap aktivitas spesifik mananase pada $\mathrm{pH} 7,2$

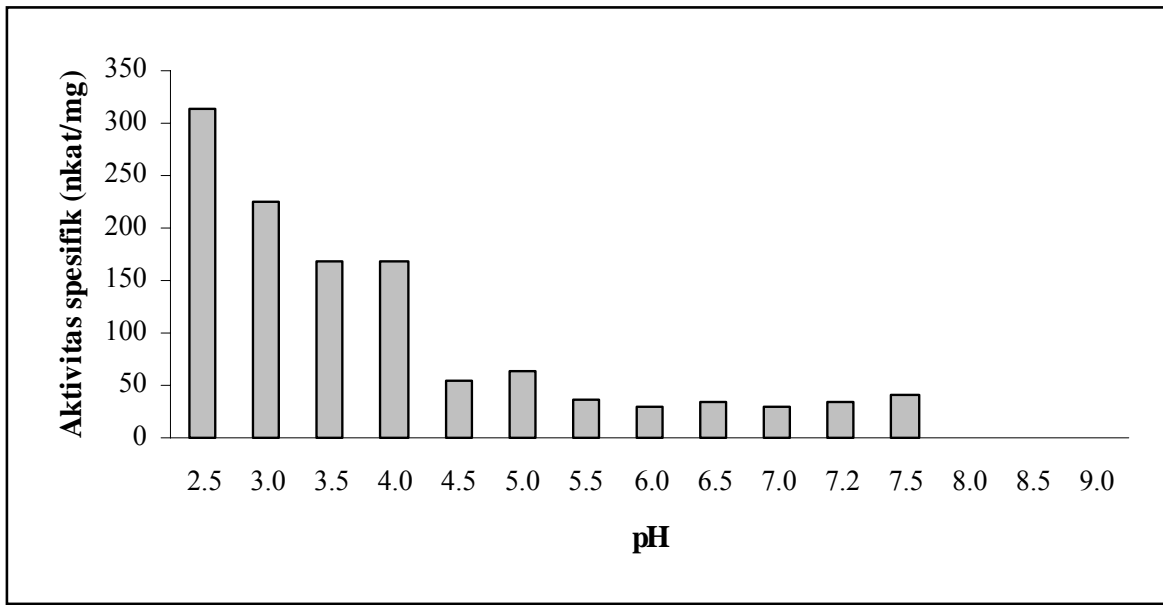

Gambar 4. Pengaruh $\mathrm{pH}$ terhadap aktivitas spesifik mananase pada suhu $80^{\circ} \mathrm{C}$

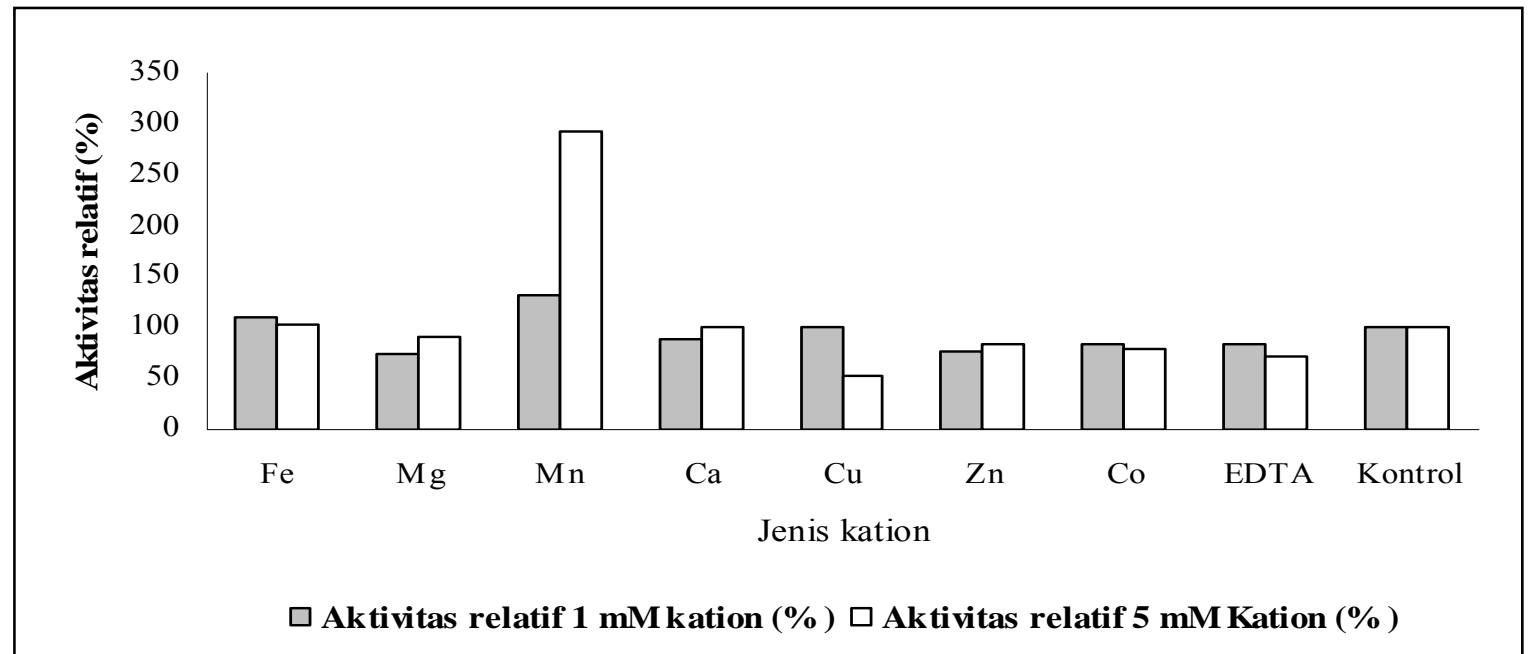

Gambar 5. Pengaruh beberapa kation divalen $1 \mathrm{mM}, 5 \mathrm{mM}$ dan EDTA terhadap aktivitas mananase yang diuji pada suhu $80^{\circ} \mathrm{C}$ dan $\mathrm{pH} 2,5$ 


\section{Kesimpulan}

Kondisi pertumbuhan dan aktivitas terbaik isolat RA05 adalah dalam $100 \mathrm{ml}$ medium dengan kecepatan agitasi $100 \mathrm{rpm}$. Medium yang mengandung bungkil kelapa 2\% lebih mampu menginduksi mananase isolat ini. Enzim mananase isolat ini memiliki aktivitas maksimum pada suhu $80^{\circ} \mathrm{C}, \quad \mathrm{pH} \quad 2,5$ membutuhkan ion $\mathrm{Mn}^{2+}$ sebesar $5 \mathrm{mM}$ dan stabil selama 4 jam. Enzim ini tidak dapat mendegradasi kolang kaling.

\section{Ucapan Terima Kasih}

Penelitian ini didanai oleh proyek Penelitian Ilmu Pengetahuan Dasar dengan kontrak nomor 63/P2IPT/DPPM/PID/III/2004 tahun 2004. Terima kasih kepada Dr. Tresnawati Purwadaria untuk diskusinya.

\section{Daftar Pustaka}

Atlas, R.M. 1997. Principles of Microbiology. New York: WBC MC Graw Hill Company.

Araujo, A. and Ward, O.P. 1990. Extracellular mannanases and galactanases from selected fungi. J. Industrial Microbiol. 6: 171-178.

Belitz, H.D. and Grosch, W. 1987. Food Chemistry. Springer Verlag.

Bradford, M.M. 1976. A rapid and sensitive method for the quantitation of microgram quantities of protein utilizing the principle of protein-dye binding. Anal. Biochem. 72: 248-254.

de Vries, R.P. and Visser, J. 2001. Aspergillus enzymes involved in degradation of plant cell wall polysaccharides. Microbiol. Mol. Biol. Rev. 65: 497-522.

Duffaud, G.D., McCutchen, C.M., Leduc, P., Parker, K.N. and Kelly, R.M. 1997. Purification and characterization of extremely thermostable $\beta$ mannanase, $\quad \beta$-mannosidase, and $\alpha$ galactosidase from the hyperthermophilic eubacterium Thermotoga neopolitana 5068. Appl. and Environmental Microbiol. 63 (1): 169-177.

Gubitz, G.M., Hayn, M., Sommerauer, M. and Steiner, W. 1996. Mannan-degrading enzymes from Sclerotium rolfsii: characterization and synergism of two endo $\beta$-mannanases and a $\beta$ mannosidase. Bioresource Technol. 58: 127135.

Hames, B.D., Hooper, N.M. and Houghton, J.D. 1997. Instant Notes in Biochemistry. Guidford: BIOS Scientific.

Hilge, M., Gloor, S.M., Rypniewski, W., Sauer, O., Heightman, T.D., Zimmermann, W., Winterhalter, K. and Piontek, K. 1998. Highresolution native and complex structures of thermostable mannanase from Thermomonospora fusca-substrate specificity in glycosil hydrolase family 5. Research article, Netherlands.

Iriani, N., Purwadaria, T., Haryati, T. dan Darma, J. 1994. Produksi mananase beberapa isolat kapang mananolitik pada substrat bungkil kelapa. Pross. Sem. Hasil Penelitian dan Pengembangan Bioteknologi; Cibinong. hlm 474-479.

Johnson, K.G. 1990. Extracellular $\beta$-mannanases from hemicellulolytic fungi. W. J. Microb. Biotechnol. 6: 209-217.

Madigan, M.T., Martinko, J.M. and Parker, J. 2006. Brock Biology of Microorganisms. Ed ke 10. New Jersey: Prentice-Hall, Inc.

Mandels M., Sternberg D. 1976.Recent advances in cellulasetechnology. Ferment Technol 54:267286.

Montiel, M.D., Hernandez, M., Rodriguez, J., Arias, M.E. 2002. Evaluation of an endo-beta-mannanase produced by Streptomyces ipomoea CECT 3341 for the biobleaching of pine kraft pulps. Appl. Microbiol. Biotechnol. 58: 67-72.

Purwadaria, T., Haryati, T. and Darma, J. 1994. Isolasi dan seleksi kapang mesofilik penghasil mananase. J. Ilmu dan Peternakan 7: 26-29.

Suhartono, M.T. 1989. Enzim dan Bioteknologi. Bogor: Antar Universitas Bioteknologi. Institut Pertanian Bogor.

Sumardi. 2004. Isolasi, karakterisasi dan produksi $\beta$ mananase ekstraseluler dari Geobacillus stearothermophilus L-07. Disertasi. Bogor: Program Pasca Sarjana Institut Pertanian Bogor.

Wang, D.I.C., Cooney, C.L., Demain, A.L., Dunhill, P., Humphrey, A.E. and Liily, M.D. 1979. Fermentation and Enzyme Technology. Kanada: John Wiley \& Sons. 